\title{
A nikkelérzékenység jelentősége az Európai Unió direktíváinak tükrében
}

\author{
Nádudvari Nóra ${ }^{1}$ - Németh Dominik dr. ${ }^{1,2}$ - Pónyai Györgyi dr. ${ }^{1}$ \\ Sárdy Miklós dr. ${ }^{1}$. Temesvári Erzsébet dr. ${ }^{1}$
}

'Semmelweis Egyetem, Általános Orvostudományi Kar, Bőr-, Nemikórtani és Bőronkológiai Klinika, Budapest ${ }^{2}$ Semmelweis Egyetem, Rácz Károly Klinikai Orvostudományok Doktori Iskola, Budapest

Bevezetés: A nikkel széleskörúen elterjedt fém és kontaktallergén. Megtalálható mindennapi használati tárgyainkban, feldolgozza az ipari termelés, és az egészségügyben is rendre bóvül alkalmazási köre. Egyidejúleg a társadalom növekvő hányadánál fordul elő nikkel-kontaktszenzibilizáció.

Célkitüzés: Az epicutan tesztelt betegcsoport adatainak feldolgozása, kiemelve a nikkelpozitív betegek megoszlását nem, életkor, diagnózis, a klinikai tünetek lokalizációja és a társult fémérzékenység szerint, továbbá a 2004 óta érvényes európai uniós Nikkel Direktivák hatásainak tanulmányozása.

Módszer: A közlemény a Semmelweis Egyetem Bőr-, Nemikórtani és Bőronkológiai Klinikájának Allergológia Laboratórium és Szakambulanciáján 1994-től 2014-ig 13693 fó (10-87 év közötti) standard környezeti epicutan sorral tesztelt beteg adatait vizsgálja retrospektív módon.

Eredmények: Az összes vizsgált bőrbeteg nikkelszenzibilizációs aránya 1994-ben 13,1\%, 2004-ben 11,5\%, 2014-ben 19,1\% volt. A nikkel-kontaktdermatitis fóként nőbetegeknél $(93,0 \%)$ fordul elő. A klinikai tünetek elsősorban a karokra és az arcra lokalizálódnak. Nikkelérzékenyeknél az allergiás kontaktdermatitis diagnózisa 65,8\%, atopiás dermatitis 9,7\%-nál fordul elő. A nikkelérzékenységhez leggyakrabban társult fémallergének a kobalt és a króm. Az 19942004-es periódushoz képest az európai uniós Nikkel Direktívákat követő 10 évben a szenzibilizáció százalékos emelkedése szignifikáns volt, ugyanakkor a nikkelpozitívak évenkénti száma csökkent. 1994-ben a betegek legnagyobb hányada (26,5\%) a 20-24 éves korcsoportba tartozott, 2004-ben szintén (20,8\%), 2014-ben azonban a 35-39 éves korosztályhoz $(15,1 \%)$.

Következtetések: A nikkelszenzibilizáció korban eltolódást mutat az idősebb korosztály felé, a 35 évesnél fiatalabb betegek száma mérséklődött. A Nikkel Direktívák révén a fiatalabbak későbbi életkorban és kisebb mértékű nikkelexpozíciónak vannak kitéve. A vizsgált betegek nikkelérzékenységének százalékos emelkedése miatt azonban újabb szabályozások bevezetése és a hatályban lévők módosítása szükségszerű.

Orv Hetil. 2021; 162(16): 629-637.

Kulcsszavak: nikkel, kontaktérzékenység, Európai Unió, direktíva

\section{Nickel sensitization: impact of the European Union Nickel Directives}

Introduction: Nickel is a widely used metal and contact allergen. It can be found in our everyday objects and it is becoming more prevalent in healthcare. Simultaneously, nickel contact sensitization occurs more frequently.

Objective: Analysis of data of patch tested patients by gender, age, diagnosis, localization of skin lesions, and associated metal sensitivity. Furthermore, to study the effects of the European Nickel Directives in force since 2004.

Method: Retrospective analysis of data of 13693 patients (aged 10-87) tested with a standard series of contact allergens at the Allergy Outpatient Unit and Laboratory of the Department, Venereology and Dermatooncology, Semmelweis University.

Result: Nickel sensitization of all examined patients was $13.1 \%$ in $1994,11.5 \%$ in 2004, and 19.1\% in 2014. Contact dermatitis occurred mainly in females $(93.0 \%)$. Skin lesions are primarily localized to the arms and face. Diagnosis of allergic contact dermatitis occurred in $65.8 \%$, and atopic dermatitis in $9.7 \%$ of tested patients. Commonly associated metal sensitivities were cobalt and chromium. In the 10 years following the Nickel Directives, the increase of the ratio of sensitized patients was significant while the number of nickel-positives per year decreased. Both in 1994 and 2004 , the largest proportion of patients belonged to the $20-24$ age group $(26.5 \%$ and $20.8 \%$, respectively), but in 2014 , to the 35-39 age group (15.1\%).

Conclusion: Nickel sensitization shifts towards the older age group, with a decrease in young patients. Because of the Nickel Directives, people are exposed to nickel at a later age and to a lesser extent. Due to the increase of the ratio of nickel-sensitive patients, it is necessary to introduce new regulations and amend the existing ones. 
Keywords: nickel, contact sensitivity, European Union, directive

Nádudvari N, Németh D, Pónyai Gy, Sárdy M, Temesvári E. [Nickel sensitization: impact of the European Union Nickel Directives]. Orv Hetil. 2021; 162(16): 629-637.

(Beérkezett: 2020. október 15.; elfogadva: 2020. november 21.)

\begin{abstract}
Rövidítések
$\mathrm{EU}=($ European Union) Európai Unió; REACH $=($ Registration, Evaluation, Authorisation and Restriction of Chemicals) a vegyi anyagok regisztrálásáról, értékeléséról, engedélyezéséról és korlátozásáról szóló rendelet; TDI = (tolerable daily intake) tolerálható napi bevitel; TENS = (transcutaneous electric nerve stimulation) transcutan elektromos idegstimuláció
\end{abstract}

A nikkel az ötödik leggyakoribb elem a Földön. Jól ötvözhető fém, az emberi szervezetben alacsony koncentrációban, nyomelemként fordul elő [1-3]. A galván- és acélipar már a XIX. század vége óta felhasználja kedvező megmunkálhatósága miatt. A fogyasztói társadalom körében az 1930-as években a bőrrel érintkező, nikkelbevonattal rendelkező tárgyak térnyerése révén vált elterjedtté a nikkel-kontaktdermatitis [1, 3, 4]. Napjainkban ugyancsak széleskörúen használt, allergizáló potenciállal rendelkező fém. Ezen tulajdonságának jelentőségét tükrözi, hogy 2008-ban „Az év kontaktallergénje” címet is kiérdemelte [3].

Európában és hazánkban is egyre gyakrabban fordulnak elő nikkel által provokált allergiás bőrreakciók. A Diepgen és mtsai által végzett felmérés szerint az európai átlagpopulációt tekintve kontaktszenzibilizáció legalább egy allergénre az esetek 27,0\%-ában volt kimutatható, a leggyakrabban a fémallergének esetében $(15,5 \%)$. Az első helyen a nikkel-szulfăt szerepelt: összesen 14,5\% szenzibilizációs gyakorisággal [5]. A társadalom növekvő hányadát érintő allergiás kontaktdermatitis jelenségére válaszul több európai ország, majd maga az Európai Unió (EU) vezetett be korlátozó intézkedéseket a nikkel felhasználási területeivel és koncentrációival, kioldódási értékeivel kapcsolatosan.

Elsőként 1989-ben Dánia maximalizálta a nikkel kioldódási koncentrációját a használati tárgyakban. Hasonló intézkedéseket 1991-ben Svédországban vezettek be, Németországban pedig kötelezően előírták a nikkeltartalmú tárgyak megjelölését [6]. Az Európai Parlament 1994-ben adta ki a nikkelre vonatkozó első irányelvét, ám annak teljes hatálybalépése csak 2001 júniusában következett be. A 94/27/EK irányelv a dán szabályozást követve határozta meg a bőrrel hosszan és közvetlen kontaktusba kerülő nikkeltartalmú tárgyak nikkelkibocsátását [7].

Ez a szabályozás az EU akkori tagállamait érintette, így Magyarországon csak később, a 2004. május 1-jei, Unióhoz történő csatlakozás után lépett érvénybe.
Az Európai Bizottság 2004-es irányelve tovább csökkentette a test átszúrt részeibe helyezhető tárgyak nikkelkibocsátási határértékét, 0,2 $\mu \mathrm{g} / \mathrm{cm}^{2} /$ hétre [8]. 2009 júniusa óta egységesen a vegyi anyagok regisztrálásáról, értékeléséről, engedélyezéséről és korlátozásáról (REACH) szóló rendelet foglalja magában a nikkelre vonatkozó szabályozásokat [9]. A kozmetikai termékekben a nikkel és vegyületeinek használatát végül 2009-ben tiltotta be az 1223/2009/EK rendelet [10].

Később az EU már az állati eredetû élelmiszerekben sem engedélyezte a nikkel-szulfát és -glükonát felhasználását [11]. 2016-ban az Európai Bizottság ajánlást fogalmazott meg a tagállamok számára a nikkel élelmiszerekben való jelenlétének nyomon követéséről a 2016-os, 2017-es, 2018-as években. A kezdeményezés célja, hogy ezáltal felmérjék a különböző élelmiszerek nikkeltartalmát, és a jövőben minél ideálisabb kockázatkezelési intézkedéseket tudjanak bevezetni [12]. 2017-ben az EU már az élelmiszerekben és az ivóvízben előforduló nikkel esetén tolerálható napi bevitel (TDI) szintjét is pontosan meghatározta, 2,8 $\mu \mathrm{g} /$ testtömegkilogramm/napban. A rendelet alapján az élelmiszerrel érintkező múanyagokra a $0,02 \mathrm{mg} /$ kilogramm élelmiszer-nikkelkioldódási határérték vonatkozik [13].

\section{Módszer}

Az epicutan tesztelésre a Semmelweis Egyetem Bőr-, Nemikórtani és Bőronkológiai Klinikájának Allergológia Laboratórium és Szakambulanciáján került sor 1994 és 2014 között. Összesen 13693 beteg bőrpróbája történt.

A betegek tesztelését standard környezeti kontakt epicutan sorral (Brial Allergen GmbH, Greven, Németország) végeztük. Antigének felviteléhez a gyártók által ajánlott Curatest ${ }^{\circledR}$ kamrás teszttapaszt (Finn Chambers on Scanpor, Epitest Ltd. Oy, Tuusula, Finnország, majd Lohmann \& Rauscher International GmbH \& Co. KG, Rengsdorf, Németország) alkalmaztuk. A környezeti standard alapsorozat 36 allergént vizsgál, ezek közül a primin és a szeszkviterpén-lakton mix 1999-ben, az epoxigyanta, a budezonid, a tixokortol-pivalát, a metil-dibromo-glutaronitril és a 'Fragrance mix II' 2007-ben, a metilizotiazolinon 2014-ben lett bevezetve. A nikkel(II)szulfát-antigén 5\%-os koncentrációban, vazelin vivőanyagban szerepel, a króm kálium-dikromátként 0,5\%-os vazelines oldatban, a kobalt kloridként, 1\%-os koncentrációban, szintén vazelinben oldva szerepel. Ezek mellett 
az antigének többségének vivőanyaga vazelin, ez alól kivétel a formalin, a propilén-glikol és a Kathon $\mathrm{CG}^{\circledR}$, amelyek vízben oldottak.

Az epicutan tesztek kiváltotta bőrreakciókat a mindenkori nemzetközi előírásoknak megfelelően értékeltük, eszerint megkülönböztettünk igen gyenge (?+), gyengén pozitív $(+)$, mérsékelten pozitív $(++)$, erősen pozitív (+++), toxikus (TR) és negatív (-) eredményeket a jellemző bőrtünetek (erythema, oedema, papula, vesicula) és az időbeli lefolyás alapján. 2007-től az Európai Kontakt Dermatitis Társaság (European Society of Contact Dermatitis) ajánlásának megfelelően a tesztek értékelését 96 órát követően a 7. napra is kibővítettük.

Retrospektív felmérésben az epicutan tesztelt bőrbetegek nikkel-kontaktszenzibilizációjának arányát és esetszámait vizsgáltuk. Figyelemmel kísértük a nikkelpozitív tesztelt beteganyagot életkor és nem szerinti megoszlás vonatkozásában is. Az életév alapján történő eloszlást az 1994-es, 2004-es és 2014-es adatokat alapul véve tanulmányoztuk, 5 éves korcsoporti bontásban. Munkánk során vizsgáltuk a diagnosztikus megoszlást, a klinikai tünetek lokalizációját, a társult fémérzékenységet. A diagnózisok regisztrálásakor allergiás kontaktdermatitis, atopiás dermatitis, dyshidrosis, seborrhoeás kórképek, psoriasis vulgaris, stasis dermatitis, prurigo, Hailey-Hailey-betegség, lupus erythematosus discoides és egyéb kórmegállapításokat magukban foglaló csoportokat különítettünk el. A tünetek lokalizációjának vizsgálatakor a kart, tenyeret, lábat, talpat, hajas fejbőrt, arcot (fül, szemhéj, száj), szájnyálkahártyát, nyakat, törzset, hónaljat és külső nemi szerveket érintő klinikai megjelenéseket különböztettünk meg. A felmérés során kitértünk a Magyarországon 2004 óta érvényes EU Nikkel Direktivák hatásainak tanulmányozására.

A betegcsoport nikkelszenzibilizációra vonatkozó adatai a Kolmogorov-Szmirnov-próba alapján normál eloszlásúnak bizonyultak. Az adatok feldolgozása során a kategorikus változók összevetésére khi-négyzet-próbát alkalmaztunk. A Nikkel Direktívák 2004. évi bevezetése előtti és utáni vizsgálati időszak folytonos változói kétmintás t-próba alapján kerültek statisztikai értékelésre. A szignifikanciaszint minden esetben $\mathrm{p}<0,05$ volt.

\section{Eredmények}

A Semmelweis Egyetem Bőr-, Nemikórtani és Bőronkológiai Klinikájának Allergológia Laboratórium és Szakambulanciáján 1994 és 2014 között összesen 13693 bőrbeteg epicutan tesztelése történt. A vizsgált beteganyag epicutan tesztelése során 1908 esetben nikkel(II)szulfát-pozitív bőrreakciót tapasztaltunk. Azonnali, urticariával járó reakció 0, késői kontaktdermatitis 1908 esetben jelentkezett. A nikkel-kontaktszenzibilizált betegek átlagéletkora 36 év volt (10-87 év). A nemek közötti megoszlás szerint 1782 fó nő volt $(93,0 \%)$, és 126 férfi $(7,0 \%)$. A nők átlagéletkora 36 évnek bizonyult, míg a férfiaké 41 évnek.
1. táblázat |A vizsgált bőrbetegek $(\mathrm{n}=13$ 693) nikkel-kontaktszenzibilizá ciós aránya, 1994-2014

\begin{tabular}{|c|c|c|c|}
\hline Év & $\begin{array}{c}\text { A vizsgált betegek } \\
\text { száma }\end{array}$ & $\begin{array}{l}\text { A nikkelérzékeny } \\
\text { betegek száma }\end{array}$ & $\begin{array}{c}\text { Nikkelérzékeny } \\
\text { betegek (\%) }\end{array}$ \\
\hline 1994 & 636 & 83 & 13,1 \\
\hline 1995 & 839 & 78 & 9,3 \\
\hline 1996 & 1099 & 129 & 11,7 \\
\hline 1997 & 938 & 119 & 12,7 \\
\hline 1998 & 802 & 91 & 11,3 \\
\hline 1999 & 834 & 88 & 10,6 \\
\hline 2000 & 797 & 99 & 12,4 \\
\hline 2001 & 799 & 81 & 10,1 \\
\hline 2002 & 698 & 79 & 11,3 \\
\hline 2003 & 701 & 88 & 12,6 \\
\hline 2004 & 670 & 77 & 11,5 \\
\hline 2005 & 637 & 81 & 12,7 \\
\hline 2006 & 612 & 90 & 14,7 \\
\hline 2007 & 538 & 110 & 20,4 \\
\hline 2008 & 514 & 110 & 21,4 \\
\hline 2009 & 512 & 95 & 18,6 \\
\hline 2010 & 480 & 96 & 20,0 \\
\hline 2011 & 401 & 84 & 20,9 \\
\hline 2012 & 413 & 77 & 18,6 \\
\hline 2013 & 390 & 80 & 20,5 \\
\hline 2014 & 383 & 73 & 19,1 \\
\hline Összesen & 13693 & 1908 & 13,9 \\
\hline
\end{tabular}

Kiemelendő a vizsgált bőrbetegek nikkel(II)-szulfátkontaktszenzibilizációs aránya. 1994 és 2005 között évente az epicutan tesztelt betegek 9,3-13,1\%-a volt érzékeny nikkelre. 2006-ban ez az érték már 14,7\%-nak, minden következő vizsgálati évben pedig még ennél is magasabbnak bizonyult. A 2006 és 2007 egymást követő évek értékeinek különbsége $(+5,7 \%)$ számottevő. A maximális szenzibilizációs gyakoriság 2008-ban adódott, ekkor a betegek $21,4 \%$-a mutatott pozitív reakciót nikkelre. A vizsgálati periódus első évében (1994) megfigyelt 13,1\%-os nikkelérzékenység gyakorisága a 2014-es év 19,1\% értékéhez képest szignifikáns eltérést jelent $\left(\chi^{2}(1, \mathrm{~N}=1019)=6,7, \mathrm{p}=0,0099, \mathrm{p}<0,05\right.$ szignifikanciaszint mellett) (1. táblázat).

A nikkelre érzékeny betegek diagnózis szerinti megoszlása is regisztrálásra került. A legnagyobb számban, 1255 fónél $(65,8 \%)$, allergiás kontaktdermatitis fordult elő. Atopiás dermatitis 9,7\% esetén igazolódott. Dyshidrosist 7,0\% arányban azonosítottunk. Seborrhoeás kórképben a betegek 6,5\%-a szenvedett. Psoriasis vulgaris $4,1 \%$, stasis dermatitis $1,1 \%$ gyakorisággal igazolódott. Az esetek 4,1\%-ánál egyéb diagnózis került megállapításra (2. táblázat).

A nikkelszenzibilizált betegek bőrtünetei a leggyakrabban a karokon (26,8\%) lokalizálódtak. Ezt követték a 
2. táblázat |A nikkelérzékeny betegek $(\mathrm{n}=1908)$ nemek szerinti diagnosztikus megoszlása

\begin{tabular}{|c|c|c|c|c|c|c|}
\hline & $\begin{array}{l}\text { A nikkelérzékeny } \\
\text { betegek száma } \\
(\mathrm{n}=1908)\end{array}$ & $\%$ & $\begin{array}{l}\text { A nikkelérzékeny } \\
\text { nóbetegek száma } \\
(\mathrm{n}=1782)\end{array}$ & $\%$ & $\begin{array}{l}\text { A nikkelérzékeny férfi } \\
\text { betegek száma } \\
(\mathrm{n}=126)\end{array}$ & $\%$ \\
\hline Allergiás kontaktdermatitis & 1255 & 65,8 & 1171 & 65,7 & 84 & 66,6 \\
\hline Atopiás dermatitis & 185 & 9,7 & 166 & 9,3 & 19 & 15,1 \\
\hline Dyshidrosis & 134 & 7,0 & 126 & 7,1 & 8 & 6,3 \\
\hline Seborrhoeás kórképek & 123 & 6,5 & 118 & 6,6 & 5 & 4,0 \\
\hline Psoriasis vulgaris & 79 & 4,1 & 77 & 4,3 & 2 & 1,6 \\
\hline Stasis dermatitis & 20 & 1,1 & 14 & 0,8 & 6 & 4,8 \\
\hline Prurigo & 12 & 0,6 & 10 & 0,6 & 2 & 1,6 \\
\hline Hailey-Hailey-betegség & 11 & 0,6 & 11 & 0,6 & 0 & 0,0 \\
\hline Lupus erythematosus discoides & 10 & 0,5 & 10 & 0,6 & 0 & 0,0 \\
\hline Egyéb* & 79 & 4,1 & 79 & 4,4 & 0 & 0,0 \\
\hline
\end{tabular}

*Egyéb: szisztémás lupus erythematosus, urticaria chronica, effluvium capillorum, alopecia, Melkersson-Rosenthal-szindróma, gingivitis, lichen amyloidosis, lichen oris, lichen sclerosus et atrophicus, lichen ruber planus, glossitis.

3. táblázat |A nikkel-kontaktszenzibilizált betegek $(\mathrm{n}=1908)$ klinikai tüneteinek lokalizációja nemek szerinti felosztásban

\begin{tabular}{|c|c|c|c|c|c|c|}
\hline & $\begin{array}{l}\text { A nikkelérzékeny betegek } \\
\text { esetszáma }(\mathrm{n}=3874)\end{array}$ & $\%$ & $\begin{array}{l}\text { A nikkelérzékeny nôbetegek } \\
\text { esetszáma }(\mathrm{n}=3610)\end{array}$ & $\%$ & $\begin{array}{l}\text { A nikkelérzékeny férfi } \\
\text { betegek esetszáma }(\mathrm{n}=264)\end{array}$ & $\%$ \\
\hline Kar & 1037 & 26,8 & 950 & 26,3 & 87 & 33 \\
\hline Törzs & 441 & 11,4 & 406 & 11,2 & 35 & 13,3 \\
\hline Láb & 388 & 10,0 & 351 & 9,7 & 37 & 14,0 \\
\hline Szemhéj & 370 & 9,6 & 360 & 10,0 & 10 & 3,8 \\
\hline Tenyér & 345 & 8,9 & 319 & 8,8 & 26 & 9,8 \\
\hline Talp & 258 & 6,7 & 239 & 6,6 & 19 & 7,2 \\
\hline Száj & 249 & 6,4 & 241 & 6,7 & 8 & 3,0 \\
\hline Arc & 230 & 5,9 & 223 & 6,2 & 7 & 2,7 \\
\hline Testszerte & 222 & 5,7 & 204 & 5,7 & 18 & 6,8 \\
\hline Nyak & 137 & 3,5 & 133 & 3,7 & 4 & 1,5 \\
\hline Külső nemi szerv & 63 & 1,6 & 57 & 1,6 & 6 & 2,3 \\
\hline Hajas fejbőr & 56 & 1,4 & 54 & 1,5 & 2 & 0,8 \\
\hline Fül & 43 & 1,1 & 42 & 1,2 & 1 & 0,4 \\
\hline Hónalj & 28 & 0,7 & 24 & 0,7 & 4 & 1,5 \\
\hline Szájnyálkahártya & 7 & 0,2 & 7 & 0,2 & 0 & 0,0 \\
\hline
\end{tabular}

törzsön $(11,4 \%)$ és a lábakon $(10,0 \%)$ megjelenő tünetek. A tünetek szemhéjérintettsége $9,6 \%$ volt. A tenyéren jelentkező panaszok 8,9\%, a talpon előfordulóak 6,7\% gyakoriságúak voltak. A száj körüli tünetek $6,4 \%$, az arcon megjelenók $5,9 \%$ arányúak voltak. Testszerte a klinikai tünetek 5,7\%-a jelentkezett. Az egyéb területek (nyak, külső nemi szervek, hajas fejbőr, fül, hónalj, szájnyálkahártya) érintettsége egyenként $5,0 \%$ alatti volt (3. táblázat).

A nikkelérzékeny betegek közül 46,7\% esetében csak nikkelre igazolódott pozitív reakció epicutan próba során, míg 53,3\%-nál társult további allergénekre is pozitivitás. A nőbetegeknél $52,8 \%$, míg a férfi betegeknél $60,3 \%$ gyakorisággal fordult elő a nikkelen kívül más kontaktallergénre való érzékenység. A nikkelérzékenységhez társult kobalt-klorid-kontaktszenzibilizáció öszszesen 16,3\% gyakorisággal fordult elő (nőbetegek: $16,8 \%$, férfi betegek: 11,2\%). Kálium-dikromát-érzékenységet a nikkelpozitív betegek 8,0\%-ánál (nóbetegek: $7,8 \%$, férfi betegek: 10,5\%) figyeltünk meg (1.ábra).

Az 1994-es, 2004-es és 2014-es évek adatait kiemelve és összehasonlítva 83,77 , illetve 73 betegnél volt kimutatható pozitív tesztreakció nikkel(II)-szulfátra. A vizsgált betegek átlagéletkora 1994-ben 30,4 év, 2004-ben 35,4 év, 2014-ben 42,4 év volt. 1994-ben 13 beteg tartozott a 15-19 éves korosztályba. A 20-24 éves életkorúak száma volt a legmagasabb az évben, 22 fövel. Az 1994-ben nikkelpozitivitást adók 26,5\%-a tartozott ebbe 
Nikkel-kontaktszenzibilizált betegek társult fémérzékenysége

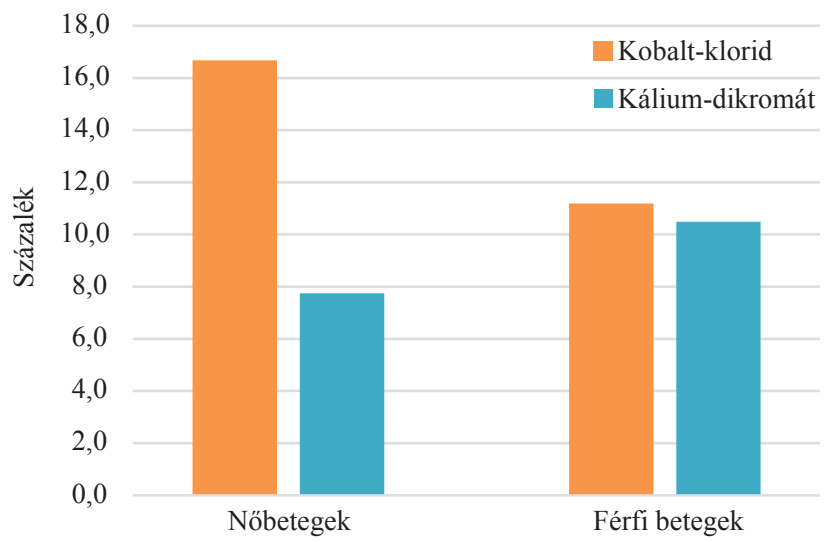

1. ábra

A nikkel-kontaktszenzibilizált betegek $(\mathrm{n}=1908)$ társult kobalt- és krómérzékenysége, külön a nóbetegek $(\mathrm{n}=1782)$ és férfi betegek ( $\mathrm{n}=126)$ százalékos értékei

az intervallumba. 2004-ben, az 1994-es évhez hasonlóan, a nikkelpozitív betegek a legnagyobb arányban a 20-24 éves korosztályba tartoztak (16 fó), ez az éves esetszám 20,8\%-át jelenti. 2014-ben a nikkelérzékeny betegek közül a 35-39 éves korosztály létszáma (11 fö, 15,1\%) volt a legmagasabb. A 40-44 évesek száma (10 fó, 13,7\%) is közelít ehhez az értékhez. A 45-49 évesek közé 9 beteg (12,3\%), az 50-54 évesekhez pedig 5 fó (6,8\%) volt sorolható. Az 55-59 éves korosztályba szintén jelentős számú beteg tartozott, 10 fơ (13,7\%) (2. ábra).

A nikkelszenzibilizált betegek évenkénti esetszámait vizsgálva két csúcsidőszak látható: az 1996-os (129 fö) és 1997-es (119 fó) év, illetve a 2007-es (110 fó) és 2008-as (110 fó) év. Az 1996-1997-es csúcs után átlagos csökkenés látható 2004-ig. Ezen időszak alatt kivételek a 2000-es és a 2003-as év, amikor kismértékü emelkedés figyelhető meg (évenként 99 és 88 beteg). 2004-től a második csúcsidőszakig esetszám-emelkedést tapasztaltunk. 2008 és 2014 között a betegek száma évről évre közel folyamatosan csökkenni látszik (kivétel a 2010-es év, 1 fó esetszám-emelkedéssel, és a 2013-as év, plusz 3 beteggel az előző évhez képest) (1. táblázat).

A nikkelszenzibilizált egyének százalékos változását a Nikkel Direktîák bevezetése elótti és utáni éveket figyelembe véve értékeltük. A 2005 és 2014 között nikkelpozitivitást adó betegcsoport $(\mathrm{M}=18,69, \mathrm{SD}=2,69)$ aránya, összehasonlítva az 1994-2004-es időszakkal ( $\mathrm{M}=$ $11,51, S D=1,12)$, szignifikáns növekedést mutat, $\mathrm{t}(19)$ $=-7,73, \mathrm{p}<0,00001, \mathrm{p}<0,05$ szignifikanciaszint mellett.

\section{Megbeszélés}

Európában és hazánkban is növekvő számban fordulnak elő allergiás bőrreakciók, az átlag 18-74 év közötti európai lakosság 27,0\%-a érzékeny legalább egy, az európai rutintesztsorban szereplő kontaktallergénre [5].

A nikkel allergizáló, dermatitises tüneteket provokáló hatásának felismerése egy időszakra tehető az ipari méretekben történő felhasználásával. Blaschko már 1889-ben leírta a fémmel kontaktusba kerülő gyári munkásokra jellemző „galvanizációs ekzema” jelenségét [14]. A nikkel okozta allergiás kontaktdermatitis klinikai jelentőségét jól mutatja, hogy Magyarországon 1948 óta szerepel az epicutan allergén standard tesztsorban [15]. Előnyös tulajdonságai miatt (könnyen megmunkálható, tartós, korrózióálló, olcsón előállítható) a nikkelt felhasználják

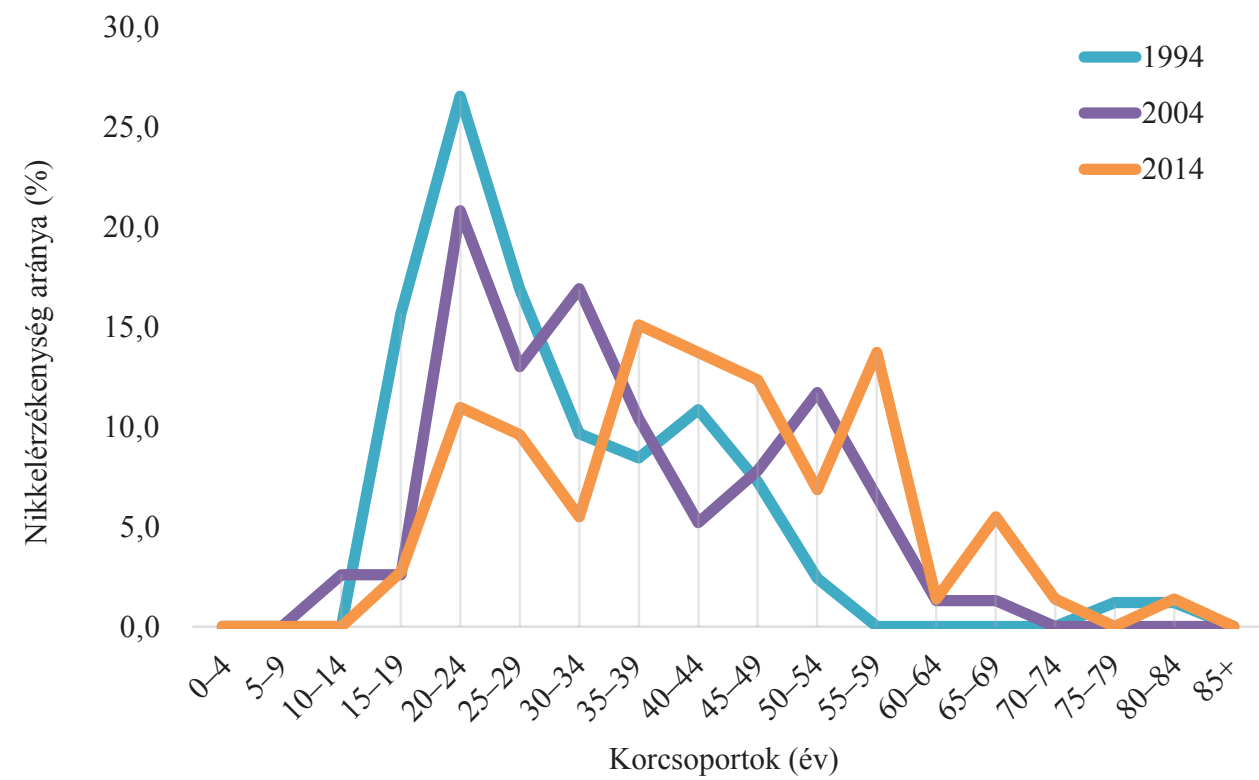




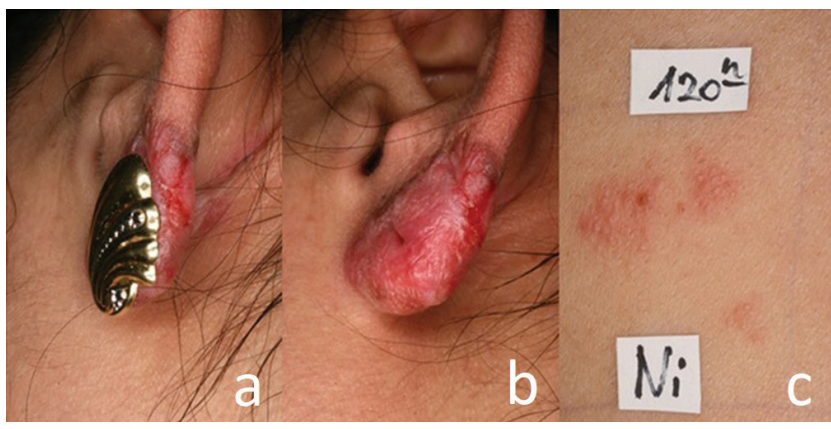

3. ábra

( $\mathrm{a}, \mathrm{b})$ Bizsu kiváltotta nikkelszenzibilizáció klinikai tünete és c) a nikkel-szulfát 120 órás epicutan próba reakciója

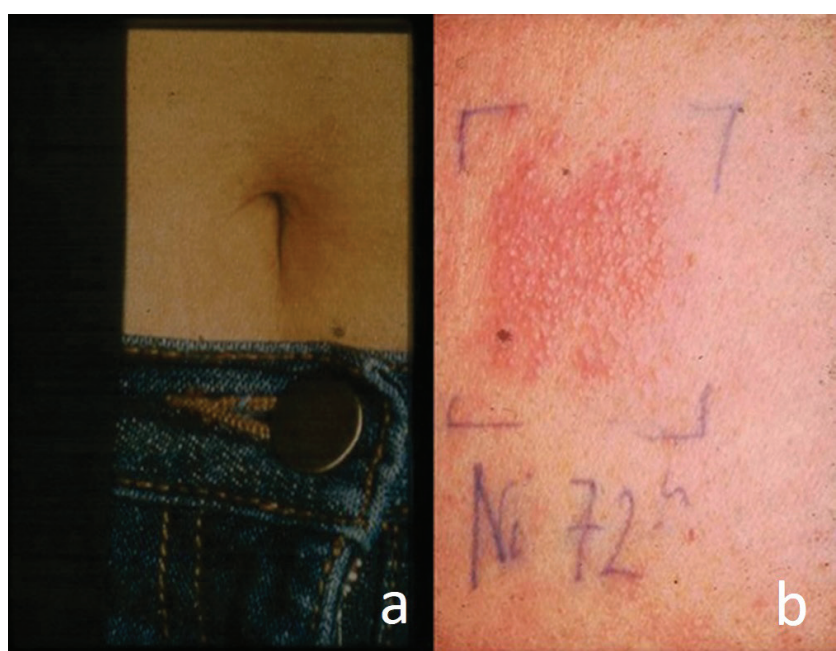

4. ábra

a) Nikkeltartalmú fémgomb provokálta ekzema tünetei és b) a beteg epicutan teszt reakciója

rozsdamentes acél, ötvözetek, mágnesek előállításához. Az akkumulátor-, acél-, építő-, festék-, galván-, gép-, hadi- és üvegipar mind-mind alkalmaz nikkelt napjainkban is $[3,16]$.

A nikkellel történő kontaktus gyakori a munkahelyi, otthoni környezetben előforduló nikkeltartalmú használati tárgyak elterjedtsége miatt. A széles körű felhasználás oka azonos az ipari területen történő térhódításával. Használati tárgyaink közül az ékszerek, mint a fülbevaló, piercing, nyaklánc, karperec, karlánc, bokaperec, gyürü és karóra; a kiegészítők, mint az óraszíj, csat, hajcsat, szegecs, gomb, cipzár és fémjelzések tartalmazhatnak nikkelt (3. és 4. ábra). Továbbá jelen lehet fém vagy ötvözetek formájában a következő tárgyakban: mobiltelefon, laptop, varrótú, olló, golyóstoll, ajtókilincs, fogantyú, öngyújtó, fém szemüvegkeret [6, 7, 17-19]. A Magyarországon forgalomban lévő pénzérmék közül mind tartalmaz eltérő tömegszázalékban nikkelt vagy nikkelborítást [20]. A kozmetikai termékek (szemhéjfesték, rúzs, körömlakk, dezodor, arclemosó, sampon, hajkondicionáló, hajfesték, folyékony szappan, fogkrém) és eszközök (szempilla-göndörítő) is lehetnek nikkeltartalmúak. A tisztítószerekben, mint a mosópor, fehérítő, mosogatószer, súrolószer, szintén fellelhető nikkel. Konyhai eszközökben (konyhaedény, serpenyő, fazék, konzervdoboz, vízcsap, mosogató, elektromos vízforraló, evőeszköz) is előfordulhat nikkel. Savas pH-t előidéző élelmiszer rozsdamentesacél edényben történő főzése okozhatja a nikkel kioldódását és feldúsulását ételeinkben. Kis mennyiségben azonosítható nikkel egyes élelmiszerekben (csokoládé, halfélék, gabonafélék, magvak, burgonya, hüvelyesek, vörösbor) és az ivóvízben is $[1,16,21]$.

Az egészségügyi, orvostechnikai eszközök fejlődésével és globálisan elérhetővé tételével további fémexpozíciós forrást jelent a nikkelnek implantátumok, protézisek és fogászati eszközök formájában történő felhasználása. Ortopéd térd-, csípő- és vállízületi protézisek, implantátumok, méhen belüli eszközök, sebészi lemezek, csavarok és csipeszek is tartalmazhatnak nikkelt. A fogászati ötvözetek, tömések, fogszabályzók között szintén előfordulhat nikkel alkotórész [16, 22]. Továbbá nikkelkomponens azonosítható a cardiovascularis eszközök - mint endovascularis sztentek, szívbillentyü-protézisek, pacemakerek, intravénás katéterek, kanülök - egy részében. A bőrrel érintkező orvostechnikai és gyógyászati eszközök, múvégtagok, hallókészülékek, kötések, szemüvegek, transcutan elektromos idegstimulátor (TENS) készülékek ugyancsak tartalmazhatnak nikkelt [3].

Az ortopédimplantátum-beültetések száma az 1960as évektől kezdve napjainkig rendre emelkedik. A várható élettartam növekedésével párhuzamosan az idősebb korosztály körében szükségszerű a fémimplantátumok, - protézisek nagyszámú alkalmazása. Az orvosi, fogorvosi implantátumok által kiváltott fémallergiás reakciók a beültetés helyén vagy generalizáltan ekzema, erythema klinikai képében jelentkezhetnek [23]. Az endovascularis sztentek többsége szintén nikkeltartalmú rozsdamentes acélból készül. Feltételezhető, hogy a nikkelszenzibilizáció a sztentelt érszakasz ismételt elzáródásának egyik kiváltó oka [24].

Nemzetközi felmérések alapján az implantátumok okozta allergiás reakciók nem gyakoriak, előfordulásuk fóként a már adott fémre szenzibilizáltak körében számottevő. Mégis figyelemre méltó megállapítás, mivel ilyen esetekben allergiás kontaktdermatitis, a protézis nem megfelelő múködése, kilazulása jelentkezhet, így annak cseréje, eltávolítása, tehát újabb mútét válhat szükségessé. Tudjuk továbbá, hogy a fémallergén-érzékenység küszöbértéke egyéni variabilitást mutat, vagyis nem ismert a várható szenzibilizáltak száma. Következésképp a lakosság fémexpozíciójának minimálisra csökkentése a cél [24, 25]. Így megelőzhető, hogy idősebb korban az implantátum beültetése, tehát a fém reexpozíciója esetén allergiás kontaktdermatitis klinikai képe jelentkezzen.

A titán ideális alternatíva implantátumok, protézisek készítésére ismert fémérzékenység esetén. Nem tartalmaz nikkelt, krómot vagy kobaltot, így elkerülhető azok szenzibilizáló, ekzemás tüneteket provokáló hatása. 
Költséges előállítása miatt azonban csak az említett magas kockázatú esetekben alkalmazzák [24, 26].

Az imént említettekből megállapítható, hogy a nikkel széleskörúen használt fémallergén. A nikkelszenzibilizált egyének allergiás kontaktdermatitise kiemelt társadalmi, egészségügyi és gazdasági probléma.

Betegeink körében a nőknél gyakrabban $(93,0 \%$ nő, $7,0 \%$ férfi) fordult elő a nikkel okozta kontaktdermatitis. Ez a megállapítás egyező eredményt mutat a nemzetközi szakirodalommal $[5,27]$. A feltételezhetô ok lehet a nók gyakoribb, fiatalabb életkorban történő és nagyobb mértékű nikkelexpozíciója a bizsuk, testékszerek és tetoválófestékek révén $[16,28]$.

Vizsgálataink során a nikkelérzékeny betegek körében a legtöbb esetben az allergiás kontaktdermatitis diagnózisa fordult elő $(65,8 \%)$. Továbbá atopiás dermatitis $(9,7 \%)$, dyshidrosis $(7,0 \%)$, seborrhoeás kórképek $(6,5 \%)$ vagy psoriasis vulgaris $(4,1 \%)$ diagnózisához társult nikkelérzékenységről beszélhetünk. A vizsgált beteganyag eredményei egyeznek a szakirodalom alapján a nikkelérzékenységgel járó, leggyakrabban provokálható bőrtünetekkel [29]. Betegeinknél nem igazolódott azonnali, nikkel okozta kontakturticaria. A szakirodalom alapján ugyancsak minimális számú esetben fordult elő nikkelpozitív I. típusú túlérzékenységi bőrreakció [30, 31].

Eredményeink alapján a nikkelérzékeny betegek klinikai tünetei a leggyakrabban a felső végtagon (35,7\%: kar és tenyér) és az arcon $(23,0 \%$, beleszámítva a fül, a szájkörnyék, a szemhéj területét) láthatók. Thyssen és mtsai szerint a nikkelérzékeny betegek bőrtünetei a kezek és az arc területén jelentkeznek a legtöbbször [2]. A korábban említett tárgyak - kiemelve a kézzel érintkező, fémből készült pénzérméket, órákat, varrótúket, mobiltelefonokat és az arccal kapcsolatba kerülő bizsukat, kozmetikai termékeket, fém szemüvegkereteket - fó kontakthelyei szintén a karok és az arc területe.

Betegeinknél a nikkelhez társult leggyakoribb fémallergénként a kobalt-klorid szerepelt (összesen: 16,3\%, nők: 16,8\%, férfiak: 11,2\%). Nikkellel együtt gyakran fordul elő ékszerekben, fém szemüvegkeretekben, karórákban [16]. Saját adataink alapján a króm a második, legtöbb alkalommal nikkelhez társult fémallergén (a nikkelérzékeny betegek 8,0\%-a pozitív krómra is, a nők 7,8\%-a, a férfiak 10,5\%-a). Magyarországon 1962 óta szerepel az epicutan tesztelésre alkalmazott allergének sorában [32]. A nikkellel többnyire együttes/ötvözeti alkalmazás és expozíció, plusz az egyedi jelentős allergizáló hatás miatt a kobaltra és a krómra is uniós szintú szabályozások bevezetése és azok nyomon követése történt [33-36].

Európán kívül a nikkelérzékenység kevésbé vizsgált jelenség, habár a szakirodalom tartósan magas prevalenciaértékeket említ mind Észak-Amerikában, mind Ázsia területén [1, 37, 38]. Az Amerikai Egyesült Államok ez idáig nem vezetett be korlátozó intézkedéseket az EUhoz hasonlóan, bár fokozott az igény rá a gyermekek és fiatalkorúak védelme és szenzibilizációjuk megelőzése érdekében [39].

Magyarországon a Nikkel Direktívák vonatkozásában az 1994-2004-es évek nikkelszenzibilizációs gyakoriságaihoz viszonyítva a 2005-2014-es intervallum szignifikáns emelkedést mutat. Az általunk vizsgált időszak első évében (1994) tapasztalt 13,1\%-os nikkelgyakoriság az utolsó, 2014-es év 19,1\%-os szenzibilizációs értékéhez képest szintén szignifikáns eltérésnek mondható. Svédországban a nikkelt érintő szabályozások előtt, majd azokat 8 évvel követően végzett kutatás során a nikkelallergia szignifikáns változását nem tapasztalták, azonban a 40 év alatti bőrbeteg nők körében néhány százalékos, de szignifikáns nikkelérzékenység-csökkenést figyeltek meg [40]. Dániában a Nikkel Direktívák bevezetése előtti eredményekhez képest szignifikáns prevalenciacsökkenést regisztráltak az 5-30 éves dermatitises nők esetében, 18 év távlatában. Ugyanakkor a 31-49 éves korosztályban ugyanezen periódus alatt szignifikáns növekedést tapasztaltak [2].

Adataink alapján a 2005 és 2014 között vizsgált bőrbetegek nikkelszenzibilizációs aránya 18,7\%. Ez az átlagérték magasabb, mint Diepgen és mtsai 2008 és 2011 között, bőrtünetektől függetlenül végzett európai felmérésének eredménye, amely szerint az átlag felnőtt populációban a nikkel-szulfát a leggyakoribb kontaktallergén: a felnőtt lakosság 14,5\%-a (nók: 22,2\%, férfiak: 5,2\%) volt érintett [5]. Megjegyzendő, hogy az EU-n belül területi különbségeket is megfigyelhetünk: a déli régiókban magasabb a nikkelérzékenyek aránya az északi országokéhoz képest [41].

Figyelmet érdemel, hogy a Nikkel Direktívák hatálybalépése utáni években Magyarországon nem a várt nikkelérzékenység-csökkenés, hanem emelkedő vagy stagnáló átlagos nikkelszenzibilizációs gyakoriságok igazolódtak. A nikkelérzékenyek abszolút száma rövid idejű emelkedés után mérséklődni látszik a direktívákat követően. Fontos hangsúlyozni, hogy emellett a tesztelt öszszbetegszám átlagosan csökkent 2003 és 2014 között. Ezen csökkent betegszámon belül a nikkelszenzitívek aránya nótt, illetve 2007-tôl 2014-ig stagnált.

Az EU tagállamai közül Dániában is megfigyelhető a direktívákat követően a nikkelérzékenység kismértékű növekedése: 16,9\% egy évvel a szabályozások bevezetése után, majd nyolc évvel később 17,2\%, a 15-41 éves nók körében. Ugyanakkor a nikkel-kontaktszenzibilizált esetek számottevően nem emelkedtek 1990 és 1998 között $[33,34]$.

Lényeges szempont a direktívák korcsoportokat érintő hatása. Az általunk vizsgált nikkel-kontaktérzékeny betegek körében megfigyelhető 2004 után a legtöbb pozitív reakciót adó korosztály megváltozása (20-24 éves betegek helyett 35-39 évesek). Következésképp a 34 évesnél fiatalabb betegek száma mérséklődött. Továbbá az 1994es évben vizsgált nikkelszenzibilizáltak átlagéletkora több mint tíz évvel módosult 2014-re: 30,4 évről 42,4 évre. Ez a változás a 2004. évi EU-direktivák bevezetésé- 
nek valószínúsíthető hatása, mivel a nikkelre vonatkozó szabályozások révén a fiatalabbak későbbi életkorban és kisebb mértékü nikkelexpozíciónak voltak kitéve. Az idősebb, feltételezhetően a direktívák bevezetése előtt már nikkelexpozíciónak kitett betegek száma növekedett a 2014-es évben.

Adatainkat tükröző eredményeket találtunk a nemzetközi szakirodalomban a korosztályos arány tekintetében. Egy több európai országot érintő felmérés során a nikkelre vonatkozó szabályozások bevezetése után szignifikáns mértékű nikkelallergia-csökkenés figyelhető meg a 30 év alatti nők körében. Hasonló adatokat regisztráltak az egyes országok a 30 év alatti férfiak esetében is. Kivétel Olaszország, ahol növekedést tapasztaltak [42]. Dániában szintén a fiatalabb generáció, a 18-35 éves nőbetegek nikkelpozitivitása csökkent $[43,44]$. A pozitivitások gyakorisága a felsőbb korosztályokban regisztrálható, aminek elsősorban terápiás következményeivel kell számolnunk, mint például protézisek, sztentek stb. esetén.

Az EU Nikkel Direktívák értékelését nehezítő tényezô azok nem azonnali hatálybalépése, ami lehetőséget ad a szabályozatlan termékek hosszabb ideig történő forgalmazásának. Továbbá a fogyasztók a korábban vásárolt árucikkeket még a korlátozások bevezetése után is használhatják, akár hosszú távon. Napjainkban egyre nagyobb probléma az EU területén kívülről érkező, tehát nem a helyi előírások szerint előállított nikkeltartalmú, -bevonatú és -összetételü fogyasztói cikkek térhódítása.

Összefoglalásként elmondható, hogy a nikkel-kontaktszenzibilizáció többségében nőbetegeknél fordul elő. A klinikai tünetek lokalizációja szempontjából kiemelt a karok és az arc területe. Az epicutan próba során nikkelpozitív reakciót adó betegek körében a legnagyobb számban az allergiás kontaktdermatitis és az atopiás dermatitis diagnózisa fordult elő. A nikkelhez a leggyakrabban egyéb fémek (kobalt, króm) érzékenysége társul. A 2004. évi Nikkel Direktivák szenzibilizációcsökkentő hatása helyett a nikkelérzékenyek százalékos arányának emelkedését tapasztaltuk. Az esetszámok azonban pár éven belül csökkenést, majd stagnálást, továbbá eloszlásbeli változásokat mutattak. A betegek jelentős hányada a 20-24 éves korcsoport helyett a 35-39 évesek közé tartozott. Ebből arra következtethetünk, hogy az idősebb generációt még a direktívák bevezetése előtt érte a - nem tudni, milyen mértékü és minőségü - nikkelexpozíció. Mivel ezen korosztály növekvő hányada nikkelérzékeny, ez komplikációkat, reexpozíciós bőrtüneteket okozhat az elsődlegesen idős betegeket érintő egészségügyi beavatkozások (sztent-, implantátum-, protézisbeültetések) elvégzése során.

\section{Következtetés}

Vizsgálati adataink alapján megállapítható, hogy az allergizált egyének számának, életkorának, nemének felmérése és a nikkelexpozíció forrásainak azonosítása az első lépés a megfelelő korlátozások bevezetéséhez és a még nem szenzibilizált egyének védelméhez. Ezenkívül a már érzékenységgel rendelkezők identifikálása lehetővé teszi számukra a reexpozíciós források felismerését és elkerülését, így biztosítva a további tünetmentességet. A nikkelexpozíció és -szenzibilizáció létrejöttének további csökkentése a cél, amihez újabb intézkedések bevezetésére, illetve az eddigi direktívák módosítására van szükség. A jelenleg elfogadott és alkalmazott direktívák távlati kiértékelése pedig a még specifikusabb és gazdaságosabb jövőbeli intézkedések bevezetéséhez járulhat hozzá.

Anyagi támogatás: A közlemény megírása, illetve a kapcsolódó kutatómunka anyagi támogatásban nem részesült.

Szerzői munkamegosztás: Anyaggyüjtés: N. N., N. D. Szakirodalom-kutatás: N. N., N. D., P. Gy. Statisztikai számítások: N. N. Szakmai és nyelvi véleményezés: P. Gy., S. M., T. E. A cikk végleges változatát valamennyi szerző elolvasta és jóváhagyta.

Érdekeltségek: A szerzőknek nincsenek érdekeltségeik.

\section{Irodalom}

[1] Ahlström MG, Thyssen JP, Wennervaldt M, et al. Nickel allergy and allergic contact dermatitis: a clinical review of immunology, epidemiology, exposure, and treatment. Contact Dermatitis 2019; 81: 227-241.

[2] Thyssen JP. Nickel and cobalt allergy before and after nickel regulation - evaluation of a public health intervention. Contact Dermatitis 2011; 65(Suppl 1): 1-68.

[3] Sas A, Németh I, Pónyai G, et al. Nickel contact allergen of the year 2008. [Nikkel, a 2008-as év kontaktallergénje.] Bőrgyógy Venerol Szle. 2009; 85: 124-130. [Hungarian]

[4] Thyssen JP, Johansen JD, Menné T. Contact allergy epidemics and their controls. Contact Dermatitis 2007; 56: 185-195.

[5] Diepgen TL, Ofenloch RF, Bruze M, et al. Prevalence of contact allergy in the general population in different European regions. Br J Dermatol. 2016; 174: 319-329.

[6] Lidén C. Nickel in jewellery and associated products. Contact Dermatitis 1992; 26: 73-75.

[7] European Parliament and Council Directive 94/27/EC. 1994; 13/13: 224-225.

[8] The Commission of the European Communities. Commission Directive 2004/96/EC. OJEU 2004; L 301: 51-52.

[9] The European Parliament and the Council of the European Union. Regulation (EC) No 1907/2006 of the European Parliament and of the Council. OJEU 2007; 136/3: 145-149.

[10] The European Parliament and the Council of the European Union. Regulation (EC) No 1223/2009 of the European Parliament and of the Council. OJEU 2009; L 342: 59-209.

[11] The European Commission. Commission Regulation (EU) No 37/2010. OJEU 2010; L 15: 1-72.

[12] The European Commission. Commission Recommendation (EU) 2016/1111. OJEU 2016; L 183: 70-71.

[13] The European Commission. Commission Regulation (EU) 2017/752. OJEU 2017; L 113: 18-23.

[14] Blaschko A. Occupational dermatoses of workers. The galvanizing eczema. [Die Berufsdermatosen der Arbeiter. Das Galvanisierekzem.] Dtsch Med Wschr. 1889; 15: 925-927. [German] 
[15] Rajka Ö. Pathogenesis of chemical occupational skin diseases. [A kémiai természetú foglalkozási bőrbetegségek pathogenesise.] Bőrgyógy Venerol Szle. 1948; 24: 289-296. [Hungarian]

[16] Basketter DA, Briatico-Vangosa G, Kaestner W, et al. Nickel, cobalt and chromium in consumer products: a role in allergic contact dermatitis? Contact Dermatitis 1993; 28: 15-25.

[17] Midander K, Hurtig A, Borg Tornberg A, et al. Allergy risks with laptop computers - nickel and cobalt release. Contact Dermatitis 2016; 74: 353-359

[18] White JM, Du Vivier AW. Occupational allergic contact dermatitis caused by nickel in embroidery needles. Contact Dermatitis 2018; 79: 181-182.

[19] Thyssen JP, Johansen JD. Mobile phones are now covered by the European Union Nickel Directive. Contact Dermatitis 2009; 61: 56-57.

[20] Magyar Nemzeti Bank. Coins. [Érméink.] Available from: https://www.mnb.hu/archivum/Bankjegy_es_erme/mnbhu_ ermek [accessed: July 23, 2020]. [Hungarian]

[21] Contact Dermatitis Institute. Nickel sulfate hexahydrate. Available from: https://www.contactdermatitisinstitute.com/pdfs/ allergens/Nickel\%20sulfate\%20hexahydrate.pdf [accessed: July $23,2020]$.

[22] Jensen CS, Lisby S, Baadsgaard O, et al. Release of nickel ions from stainless steel alloys used in dental braces and their patch test reactivity in nickel-sensitive individuals. Contact Dermatitis 2003; 48: 300-304

[23] Kanerva L, Förström L. Allergic nickel and chromate hand dermatitis induced by orthopaedic metal implant. Contact Dermati tis $2001 ; 44: 103-104$.

[24] Thyssen JP, Johansen JD, Menné T, et al. Hypersensitivity reactions from metallic implants: a future challenge that needs to be addressed. Br J Dermatol. 2010; 162: 235-236.

[25] Teo WZ, Schalock PC. Metal hypersensitivity reactions to orthopedic implants. Dermatol Ther (Heidelb). 2017; 7: 53-64.

[26] Gawkrodger DJ. Nickel sensitivity and the implantation of orthopaedic prostheses. Contact Dermatitis 1993; 28: 257-259.

[27] Uter W, Pfahlberg A, Gefeller O, et al. Risk factors for contact allergy to nickel - results of a multifactorial analysis. Contact Dermatitis 2003; 48: 33-38.

[28] Council of Europe, Committee of Ministers. Resolution ResAP(2008)1 on requirements and criteria for the safety tattoos and permanent make-up. Available from: http://www.abcink. biz/pdf/ResApp2008-1_en.pdf [accessed: July 23, 2020].

[29] Kárpáti S, Gyulai R, Kemény L, et al. (eds.) Dermatology and venereology. [Börgyógyászat és venerológia.] Medicina Könyvkiadó, Budapest, 2020; pp. 270-279. [Hungarian]

[30] Osmundsen PE. Contact urticaria from nickel and plastic additives (butylhydroxy-toluene, oleylamide). Contact Dermatitis 1980; 6: 452-454.

[31] Estlander T, Kanerva L, Tupasela O, et al. Immediate and delayed allergy to nickel with contact urticaria, rhinitis, asthma and contact dermatitis. Clin Exp Allergy 1993; 23: 306-310.
[32] Valér M, Somogyi Z, Palus V. Data on the issue of chromallergy. Studies on the sensitization of trivalent chromium salts. [Adatok a chromallergia kérdéséhez. A 3 vegyértékû́ krómsók szenzibilizáló kézségére vonatkozó vizsgálatok.] Bőrgyógy Venerol Szle. 1962; 38: 249-259. [Hungarian]

[33] Nielsen NH, Menné T. Allergic contact sensitization in an unselected Danish population. The Glostrup Allergy Study, Denmark. Acta Derm Venereol. 1992; 72: 456-460. [Erratum: Acta Derm Venereol (Stockh). 1993; 73: 397.]

[34] Nielsen NH, Linneberg A, Menné T, et al. Allergic contact sensitization in an adult Danish population: two cross-sectional surveys eight years apart (the Copenhagen Allergy Study). Acta Derm Venereol. 2001; 81: 31-34.

[35] Schäfer T, Böhler E, Ruhdorfer S, et al. Epidemiology of contact allergy in adults. Allergy 2001; 56: 1192-1196.

[36] Fall S, Bruze M, Isaksson M, et al. Contact allergy trends in Sweden - a retrospective comparison of patch test data from 1992, 2000, and 2009. Contact Dermatitis 2015; 72: 297-304.

[37] Rietschel RL, Fowler JF, Warshaw EM, et al. Detection of nickel sensitivity has increased in North American patch-test patients. Dermatitis 2008; 19: 16-19.

[38] Dou X, Zhao Y, Ni C, et al. Prevalence of contact allergy at a dermatology clinic in China from 1990-2009. Dermatitis 2011; 22: 324-331.

[39] Jacob SE, Moennich JN, Mckean BA, et al. Nickel allergy in the United States: a public health issue in need of a "nickel directive". J Am Acad Dermatol. 2009; 60: 1067-1069.

[40] Lindberg M, Edman B, Fischer T, et al. Time trends in Swedish patch test data from 1992 to 2000. A multi-centre study based on age- and sex-adjusted results of the Swedish standard series. Contact Dermatitis 2007; 56: 205-210.

[41] Ahlström MG, Thyssen JP, Menné T, et al. Prevalence of nickel allergy in Europe following the EU Nickel Directive. A review. Contact Dermatitis 2017; 77: 193-200.

[42] Garg S, Thyssen JP, Uter W, et al. Nickel allergy following European Union regulation in Denmark, Germany, Italy and the U.K. Br J Dermatol. 2013; 169: 854-858.

[43] Lidén C, Andersson N, Julander A, et al. Cobalt allergy: suitable test concentration, and concomitant reactivity to nickel and chromium. Contact Dermatitis 2016; 74: 360-367.

[44] Thyssen JP, Linneberg A, Menné T, et al. The association between hand eczema and nickel allergy has weakened among young women in the general population following the Danish nickel regulation: results from two cross-sectional studies. Contact Dermatitis 2009; 61: 342-348.

(Nádudvari Nóra dr., Budapest, Mária u. 41., 1085 e-mail: nadudvari0nora@gmail.com)

A cikk a Creative Commons Attribution 4.0 International License (https://creativecommons.org/licenses/by/4.0/) feltételei szerint publikált Open Access közlemény, melynek szellemében a cikk bármilyen médiumban szabadon felhasználható, megosztható és újraközölhető, feltéve, hogy az eredeti szerző és a közlés helye, illetve a CC License linkje és az esetlegesen végrehajtott módosítások feltüntetésre kerülnek. (SID_1) 